\title{
Knowledge of Diabetes Mellitus and Management Practices among Senior High School Teachers in Ghana
}

\author{
Immanuel Amissah $^{1}$, Nana Ama Barnes ${ }^{2}$, Joshua Panyin Craymah ${ }^{3}$, Sebastian Eliason ${ }^{4}$ \\ 1, 2, 3 Department of Internal Medicine\& Therapeutics,University of Cape Coast School of Medical Sciences \\ ${ }^{4}$ Department of Community Medicine, University of Cape Coast School of Medical Sciences
}

\begin{abstract}
Background: Educating teachers on diabetes mellitus is crucial to facilitate the appropriate care of the child with diabetes mellitus. The objectives of this study were (1) to determine the knowledge deficits about diabetes among school teachers in Ghana (2) to determine the knowledge on diabetes management practices among Senior High School teachers. Methods: A cross sectional descriptive study was carried out among 215 senior high school teachers from the western and central regions of Ghana. Data was collected using self-administered questionnaires during the period August,2015 to February,2016. Results: Majority of the teachers (97\%) knew that diabetes is as a result of increased blood sugar levels. Majority (81.8\%) of the teachers knew that DM can cause complications in other organs and only $20.0 \%, 15.8 \%, 7.5 \%$ and $21.3 \%$ perceived obesity, decreased physical activity, stress and consuming too much sugars and sweets respectively as risk factors of type 2 diabetes mellitus. Majority of the teachers reported television and radio as the main source of information for DM. Only $31 \%$ knew the treatment for low blood sugar is to drink some sugar containing drink or eat food, but majority (75\%) also knew that exercise lowers blood sugar. The most important DM management practices reported by the teachers were to allow student to see the school nurse upon request; discussing with parent about student condition and school to provide diabetic training for teachers; student to have access to fluids and to have competency in using glucometer. DM management practices that were considered not important by the teachers were preventing diabetic student to take part in school excursions; preventing diabetic student from exercising at school; diabetic student to eat his or her meal anywhere in school; allowing student to perform self-injection of insulin; permission for student to check his/her blood sugar level in school and keeping sugar in class to treat low blood sugar. Conclusion: Our study results indicate that teachers have limited knowledge about diabetes management and practices and therefore there is the need of diabetes education training courses for school teachers to enable them to provide adequate care for children with diabetes.
\end{abstract}

Keywords: Diabetes Mellitus, Senior High School Teachers, management practices, knowledge, Ghana.

\section{Introduction}

Diabetes prevalence is increasing globally, and Sub-Saharan Africa is no exception. The world is currently experiencing an epidemic of diabetes mellitus (DM). There were 266,200 cases of diabetes in Ghana in 2015 (IDF,2015).Diabetes mellitus (DM) is one of the most common chronic childhood diseases (ADA,2002), and the global incidence of type 1 diabetes in children below 14 years is increasing with an estimated overall annual increase of around 3\% (Wild et al, 2004).

The majority of these children attend school and/or some type of day care, where they spend up to 10 hours a day in contact with the staff of the schools and the need for the staff to be knowledgeable in diabetes management, thereby providing a safe school environment. Crucial to achieving blood glucose control is an understanding of the effects of physical activity, nutrition therapy, and insulin on blood glucose levels. Younger children may not be adept at dealing with acute emergencies such as hypoglycemia (low blood sugar) and will be dependent upon the adult caring for them at the time; which in school time is the teacher. Teachers also need to be aware of the dietary needs of children with diabetes and of the need to take extra carbohydrate before exercise.

Diabetes management in school is the school's assistance and support to assure that the student who has diabetes feels safe and secure in the classroom setting, to have a normal lifestyle and a positive school experience. This can be done through meetings with the family, teachers, other school personnel, health care providers, collectively develop an understanding of diabetes related needs of the individual student and develop individualized action plans for routine care, safety and emergencies (Wagner et al, 2007).

Effective diabetes management at school has numerous positive outcomes. It can promote a healthy, productive learning environment, promote full participation in all curricular and extra-curricular activities, achieve glucose control, and help assure effective response in case of diabetes-related emergency and better academic achievement (ADA,2012).

Educating teachers on DM is crucial to facilitate the appropriate care of the student with DM. Both parents and the health care team must work together to provide school staff with the information necessary to allow children with diabetes to participate fully and safely in the school experience (ADA, 2012).

Despite the universal advocacy regarding appropriate care for children with diabetes in the school (ADA, 2008), inadequate diabetes knowledge, attitude and management among school personnel and worry about diabetes emergencies at school are still reported. Studies have shown that parents of children with diabetes lack confidence in their teachers' ability to manage diabetes effectively (Nabors et al, 2003; Husband et al, 2001). 


\section{International Journal of Science and Research (IJSR) \\ ISSN (Online): 2319-7064}

Index Copernicus Value (2015): 78.96 | Impact Factor (2015): 6.391

A study in Egypt by Ensaf and Gawwad (2008) found that only 18.6 percent of teachers had got good total score of diabetes management practices for their diabetic students. The most frequent practices mentioned were trying to have competency in using glucometer, and allowing students to use restroom as needed. Developing an emergency action plan and monitoring diabetic students during school hours were the least mentioned practices.

A qualitative study in Ghana carried out by Kratzer, J (2012) to look at the structural barriers to coping with type $1 \mathrm{DM}$ showed that parents were worried that teachers wouldn't remember to give their child a snack break at the appropriate times. In that same study, another parent also stated that whiles physical activity is a recommended component of properly managing diabetes; teachers restricted her daughter from athletic activities enjoyed by the rest of the class. The parents recalled that teachers expressed concern that she can go into a coma, and they did not know how to deal with it.

Studies by Aycan et al (2012) carried out in Turkey also showed that teachers had limited knowledge on diabetes. These studies indicate both a lack of diabetic knowledge and the inadequacy of information offered to teachers.

Studies on knowledge of DM among school teachers are lacking in Ghana and results of such findings may help policy makers to determine diabetes training needs of school teachers and their readiness to assist children in diabetes management when necessary. The aim of the study was to determine the knowledge of diabetes among school teachers in Ghana in order to determine their diabetes training needs and their preparedness to provide adequate care for children with diabetes. The specific objectives were: to determine the knowledge deficits about diabetes among school teachers in Ghana; to determine the knowledge on diabetes management practices among Senior High School teachers.

\section{Methodology}

A cross-sectional descriptive study was carried out among 215 randomly sampled Senior High School teachers in the Central and Western Regions of Ghana during the period of August, 2015 to February, 2016. Approval for the study was sought by contacting the headmasters and headmistresses of the various schools through personal meeting to orient them about the purpose of the study and get their permission to conduct the study. The inclusion criteria were teachers affiliated to the chosen schools who agree to participate in the study. The exclusion criteria were teachers who declined to participate, incompletely filled questionnaire and nonteaching staff.

A self-administered structured questionnaire was used for data collection. The questionnaire was grouped into three sections. The first section included data about sociodemographic characteristics, teaching experience, subject taught, their position in school, knowledge of any child with diabetes in their class. The second section consisted of questions to assess teachers' knowledge on diabetes, which comprises of 19 YES/NO items entailing types of DM, causes, signs and symptoms of hypoglycemia and hyperglycemia, risk factors, effects of diet and exercise on blood sugar. In order to correct for "guessing", each question included an option answer, "I don't know".

Teachers' knowledge toward diabetes management practices was assessed using 20 statements, using 4 points Likert scale options (not important, somewhat important, important, and very important). This section elicited the teachers' attitude toward the student with diabetes relevant to the school environment, views about teachers and family responsibility to take care for these students, their role in educating students about DM, their readiness to manage DM emergencies and their willingness to receive training about diabetes. The teachers' management practices scale was developed based on the American Diabetes Association (2012) recommendations for diabetes care in schools (ADA, 2012).

\section{Statistical Analysis}

Descriptive analysis of the data was done using SPSS version 19 (SPSS Inc, Chicago, IL). Univariate analysis such as proportions and bar graph were conducted to provide a summary on the socio demographic characteristics, sources of information, teachers' knowledge on diabetes mellitus,and diabetes management practices.

\section{Results}

Table 1: Socio-demographic characteristics of respondents

\begin{tabular}{|l|l|l|}
\hline Characteristics & Frequency(N) & Percent (\%) \\
\hline Age & & \\
\hline $20-29$ & 35 & 17.3 \\
\hline $30-39$ & 102 & 50.5 \\
\hline $40-49$ & 48 & 23.8 \\
\hline $50-59$ & 17 & 8.4 \\
\hline Total & 202 & 100.0 \\
\hline Gender & & \\
\hline Male & 176 & 82.6 \\
\hline Female & 37 & 17.4 \\
\hline Total & 213 & 100.0 \\
\hline Marital status & & \\
\hline Single & 66 & 30.8 \\
\hline Married & 143 & 66.8 \\
\hline Courting & 5 & 2.3 \\
\hline Total & 214 & 100.0 \\
\hline Educational level & & \\
\hline SHS/Vocational & 2 & 0.9 \\
\hline Tertiary/Polytechnic & 127 & 59.1 \\
\hline Postgraduate & 86 & 40.0 \\
\hline Total & 215 & 100.0 \\
\hline Religion & & \\
\hline No religion & 4 & 1.9 \\
\hline Christian & 188 & 87.9 \\
\hline Islam & 22 & 10.3 \\
\hline Total & 214 & 100.0 \\
\hline Years of teaching & & \\
\hline$<1$ year & 14 & 6.5 \\
\hline $1-5$ years & 68 & 31.8 \\
\hline $6-10$ years & 38 & 17.8 \\
\hline $11-15$ years & 41 & 19.2 \\
\hline $16-20$ years & 30 & 14.0 \\
\hline$>20$ years & 23 & 10.7 \\
\hline Total & 214 & 100.0 \\
\hline & & \\
\hline & & \\
\hline & & \\
\hline
\end{tabular}

\section{Volume 6 Issue 1, January 2017}




\section{International Journal of Science and Research (IJSR) \\ ISSN (Online): 2319-7064}

Index Copernicus Value (2015): 78.96 | Impact Factor (2015): 6.391

\begin{tabular}{|l|l|l|}
\hline Subject taught & & \\
\hline Science & 59 & 28.9 \\
\hline Mathematics & 29 & 14.2 \\
\hline Arts/Social Sciences & 73 & 35.8 \\
\hline Business & 35 & 17.2 \\
\hline Vocational/Technical & 8 & 3.9 \\
\hline Total & 204 & 100.0 \\
\hline
\end{tabular}

\section{Demographics of study Respondent's}

A total of 215 respondents' (82.6\% males; $17.4 \%$ females) participated in the study. Majority of the respondents were within the 30-39 age group (50.5\%), followed by the $40-49$ age group (23.8\%) respectively. The mean age of the school teachers was $36.8 \pm 8.0$ years. Majority $(66.8 \%)$ were married. The highest educational level of the teachers were tertiary $(59.1 \%)$, with $40.0 \%$ of them with postgraduate education. Majority (31.8\%)have taught for 1-5 years; $10.7 \%$ with $>20$ years of teaching experience. Most subjects taught were arts\& social sciences and science by $35.8 \%$ and $28.9 \%$ of the teachers respectively (Table 1 ).

\section{Sources of information about Diabetes}

Figure 1 depicts sources of information about diabetes by the teachers. Majority $(28.7 \%)$ reported television as the main source of information, followed by radio (21.6\%). Majority $(81 \%)$ of the teachers also reported that diabetes education should be added to the school curriculum.

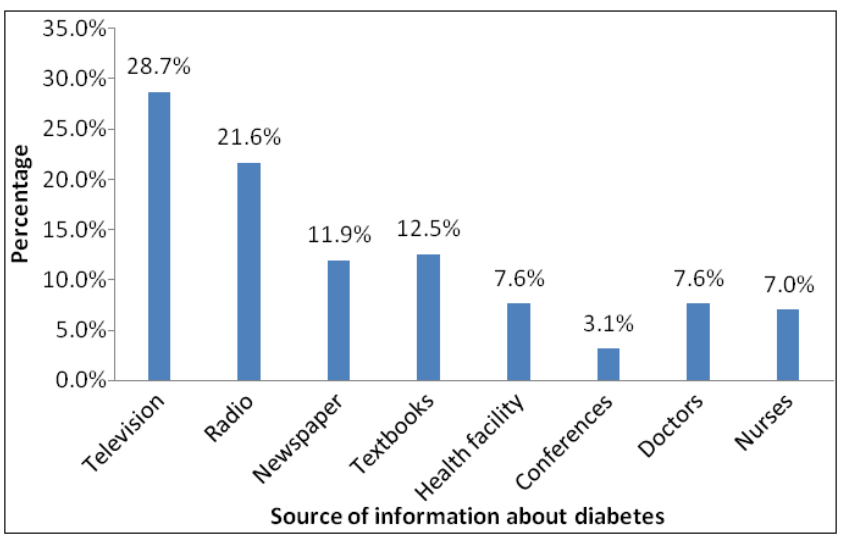

Figure 1: Sources of information about diabetes

\section{Teachers' knowledge on Diabetes Mellitus}

Knowledge on elements of DM is shown in Table 2. Majority $(97.0 \%)$ of the teachers knew that diabetes is as a result of increased blood sugar levels. Majority (39.1\%) did not know the types of DM, but $31.9 \%, 23.0 \%$ and $6.0 \%$ knew about type 1, type 2 and gestational diabetes mellitus respectively. Frequent urination was identified as a symptom of DM by $67.8 \%$ of the teachers, followed by tiredness $(53.6 \%)$, weight loss $(53.2 \%)$ and excessive thirst and hunger $(46.1 \%)$ respectively.

Majority $(81.8 \%)$ of the teachers knew that DM can cause complications in other organs. Poor wound healing were identified as complication by $84.8 \%$ of the teachers, followed by foot ulcers and amputation (76.4\%), kidney problems $(69.5 \%)$, heart problems $(65.7 \%)$, vision problems $(61.2 \%)$ and loss of feelings in hands, fingers and feet $(56.0 \%)$ respectively.

About 136 (35.3\%) of teachers perceived family history as an important risk factor for developing DM and only $20.0 \%$, $15.8 \%, 7.5 \%$ and $21.3 \%$ perceived obesity, decreased physical activity, stress and consuming too much sugars and sweets respectively as risk factors for DM.Only 88 (42.3\%) were able to identify shaking and sweating as a sign of low blood sugar. Only $66(31.0 \%)$ knew the treatment for low blood sugar is to drink some sugar containing drink or eat food, but majority (40.1\%) reported that fruit juice raises blood sugar. Majority 159 (75\%) also knew that exercise lowers blood sugar.

Teachers' knowledge on diabetes management practices. Table 3 shows teachers' knowledge on diabetes management practices for children with diabetes. The most very important DM management practices reported by the teachers were to allow student to see the school nurse upon request $(60.5 \%)$, followed by discussing with parent about student condition $(59.7 \%)$, and followed by school to provide diabetic training for teachers $(57.8 \%)$ respectively.

Other practices that were deemed very important by the teachers are student to have access to fluids (49.3\%), talking about diabetes with diabetic student and all students (47.9\%) and to have competency in using glucometer (46.0\%).

Diabetes management practices that were considered not important by the teachers were preventing diabetic student to take part in school excursions $(64.8 \%)$, preventing diabetic student from exercising at school $(57.6 \%)$, diabetic student to eat his or her meal anywhere in school $(52.2 \%)$, allowing student to perform self injection of insulin (42.1\%), permission for student to check his/her blood sugar in school $(35.2 \%)$ and keeping sugar in class to treat low blood sugar $(34.6 \%)$.

Table 2: Teachers Knowledge on Diabetes Mellitus

\begin{tabular}{|l|c|}
\hline \multicolumn{1}{|c|}{ Knowledge } & $\begin{array}{c}\text { Yes Responses } \\
\text { N }(\%)\end{array}$ \\
\hline $\begin{array}{l}\text { 1.Diabetes is as a result of: } \\
\text { Increased blood sugar levels }\end{array}$ & $191(97.0)$ \\
Decreased blood sugar levels & $6(3.0)$ \\
\hline 2.Types of DM: & $79(31.9)$ \\
Type 1 diabetes & $57(23.0)$ \\
Type 2 diabetes & $17(6.0)$ \\
Gestational diabetes & $97(39.1)$ \\
Don't Know & \\
\hline 3. Symptoms of DM: & $143(67.8)$ \\
Frequent urination & $111(53.6)$ \\
Tiredness & $109(53.2)$ \\
Weight loss & $95(46.1)$ \\
Excessive thirst and hunger & $171(81.8)$ \\
\hline 4. DM can cause complications in other & \\
organs & \\
\hline 5. Complications of DM: & $178(84.8)$ \\
Poor wound healing & $141(69.5)$ \\
Kidney problems & $116(56.0)$ \\
Loss of feelings in hands, fingers and feet & $128(61.2)$ \\
Vision problems & $138(65.7)$ \\
Heart Problems & $159(76.4)$ \\
Foot ulcers and amputation & \\
\hline 6. Risk factors for type 2 DM: & $77(20.0)$ \\
Obesity & $61(15.8)$ \\
Decreased physical activity & $136(35.3)$ \\
Family history of diabetes & $29(7.5)$ \\
Stress & \\
\hline
\end{tabular}

\section{Volume 6 Issue 1, January 2017} www.ijsr.net 
International Journal of Science and Research (IJSR)

ISSN (Online): 2319-7064

Index Copernicus Value (2015): 78.96 | Impact Factor (2015): 6.391

\begin{tabular}{|l|c|}
\hline Consuming too much sugars and sweets & $82(21.3)$ \\
\hline $\begin{array}{l}\text { 7. Shaking and sweating are signs of low } \\
\text { blood sugar }\end{array}$ & $88(42.3)$ \\
\hline $\begin{array}{l}\text { 8. Frequent urination and thirst are signs } \\
\text { of high blood sugar }\end{array}$ & $120(57.8)$ \\
\hline 9. How to treat low blood sugar: & \\
Exercise & $69(32.4)$ \\
Lie down and rest & $8(3.8)$ \\
Drink some sugar containing drink or eat & $66(31.0)$ \\
food & \\
Don't know & $70(32.9)$ \\
\hline 10. Effect of fruit juice on blood sugar: & \\
Lowers it & $22(10.4)$ \\
Raises it & $85(40.1)$ \\
Has no effect & $25(11.8)$ \\
Don't know & $80(37.7)$ \\
\hline 11. Effect of exercise on blood sugar: & \\
Lowers it & $159(75.0)$ \\
Raises it & $3(1.4)$ \\
Has no effect & $8(3.8)$ \\
Don't know & $42(19.8)$ \\
\hline
\end{tabular}

Table 3: Teachers Knowledge on diabetes management practices

\begin{tabular}{|c|c|c|c|c|}
\hline $\begin{array}{c}\text { Management } \\
\text { Practices }\end{array}$ & \multicolumn{4}{|c|}{ Frequency \% } \\
\cline { 2 - 5 } & $\begin{array}{c}\text { Not } \\
\text { important }\end{array}$ & $\begin{array}{c}\text { Somewhat } \\
\text { important }\end{array}$ & Important & $\begin{array}{c}\text { Very } \\
\text { important }\end{array}$ \\
\hline $\begin{array}{c}\text { 1.To have } \\
\text { competency in } \\
\text { using glucometer }\end{array}$ & $8(3.7)$ & $22(10.2)$ & $86(40.0)$ & $99(46.0)$ \\
\hline $\begin{array}{c}\text { 2.Allowing } \\
\text { student with } \\
\text { diabetes to use } \\
\text { restroom }\end{array}$ & $31(14.5)$ & $55(25.7)$ & $82(38.3)$ & $46(21.5)$ \\
\hline $\begin{array}{c}\text { 3.Allowing } \\
\text { student to perform } \\
\text { self injection of } \\
\text { insulin }\end{array}$ & $90(42.1)$ & $35(16.4)$ & $50(23.4)$ & $39(18.2)$ \\
\hline $\begin{array}{c}\text { 4.Permission for } \\
\text { student to check } \\
\text { his/her blood } \\
\text { sugar in school }\end{array}$ & $75(35.2)$ & $44(20.7)$ & $51(23.9)$ & $43(20.2)$ \\
\hline $\begin{array}{c}\text { 5.To have } \\
\text { competency in } \\
\text { insulin injection }\end{array}$ & $15(7.4)$ & $32(15.8)$ & $84(41.4)$ & $72(35.5)$ \\
\hline $\begin{array}{c}\text { 6.Preventing } \\
\text { diabetic student } \\
\text { from eating sweet } \\
\text { at school }\end{array}$ & $19(9.4)$ & $22(10.9)$ & $70(34.7)$ & $91(45.0)$ \\
\hline $\begin{array}{c}\text { 7.Diabetic student } \\
\text { to eat his/her meal } \\
\text { anywhere in } \\
\text { school }\end{array}$ & $109(52.2)$ & $37(17.7)$ & $39(18.7)$ & $24(11.5)$ \\
\hline $\begin{array}{c}\text { 8.Talking about } \\
\text { diabetes with } \\
\text { diabetic student } \\
\text { and all }\end{array}$ & $24(11.4)$ & $18(8.5)$ & $68(32.2)$ & $101(47.9)$ \\
\hline $\begin{array}{c}\text { 9.Make list of } \\
\text { diabetic student } \\
\text { medications and } \\
\text { usage }\end{array}$ & $24(11.4)$ & $31(14.8)$ & $80(38.1)$ & $75(35.7)$ \\
\hline $\begin{array}{c}\text { 10.Reminding } \\
\text { diabetic student to } \\
\text { take snack at time } \\
\text { schedule } \\
\text { the school nurse } \\
\text { upon request }\end{array}$ & $16(7.7)$ & $36(17.2)$ & $79(37.8)$ & $78(37.3)$ \\
\hline 12.Keeping sugar & $72(34.6)$ & $39(18.8)$ & $58(27.9)$ & $39(18.8)$ \\
\hline
\end{tabular}

\begin{tabular}{|c|l|l|l|l|}
\hline $\begin{array}{c}\text { in class to treat } \\
\text { low blood sugar }\end{array}$ & & & & \\
\hline $\begin{array}{c}\text { 13.Asking parent } \\
\text { to provide } \\
\text { glucometer to the } \\
\text { school }\end{array}$ & $38(18.1)$ & $38(17.7)$ & $70(33.3)$ & $64(30.5)$ \\
\hline $\begin{array}{c}\text { 14.Observe } \\
\text { diabetic student at } \\
\text { all day at school }\end{array}$ & $32(15.2)$ & $48(22.7)$ & $82(38.9)$ & $49(23.2)$ \\
\hline $\begin{array}{c}\text { 15.Preventing } \\
\text { diabetic student } \\
\text { from exercising at } \\
\text { school }\end{array}$ & $121(57.6)$ & $39(18.6)$ & $29(13.8)$ & $21(10.0)$ \\
\hline $\begin{array}{c}\text { 16.Discussing } \\
\text { with parent about } \\
\text { student condition }\end{array}$ & $4(1.9)$ & $14(6.6)$ & $67(31.8)$ & $126(59.7)$ \\
\hline $\begin{array}{c}\text { 17.School should } \\
\text { provide diabetic } \\
\text { training for } \\
\text { teachers }\end{array}$ & $6(2.8)$ & $18(8.5)$ & $65(30.8)$ & $122(57.8)$ \\
\hline $\begin{array}{c}\text { 18.Student to have } \\
\text { access to } \\
\text { fluids(i.e. water) }\end{array}$ & $4(1.9)$ & $14(6.6)$ & $89(42.2)$ & $104(49.3)$ \\
\hline $\begin{array}{c}\text { 19.Prevent } \\
\text { diabetic student to } \\
\text { take part in school } \\
\text { excursions }\end{array}$ & $136(64.8)$ & $32(15.2)$ & $25(11.9)$ & $17(8.1)$ \\
\hline
\end{tabular}

\section{Discussion}

Studies on the knowledge of DM and its management practices by school teachers in Ghana are not available. Our study provided insights about teachers understanding of DM and how they will manage children with DM in school, which can lay the groundwork for future training of school teachers and policy.

To achieve good blood glucose control,a child must check blood glucose frequently, monitor food intake, take medications and engage in regular physical activity (ADA,2008), and to facilitate the appropriate care of the student with diabetes, the school nurse as well as other school and day care personnel must have an understanding of diabetes and must be trained in its management and in the treatment of diabetes emergencies (NIH,2012;ADA,2012).

Knowledgeable trained personnel are essential if the student is to avoid the immediate health risks of low blood glucose and to achieve the metabolic control required to decrease risks for later development of diabetes complications. Various research studies have shown that children with DM do not have appropriate diabetes care in school (Hayes-Bohn et al,2004; Lewis et al, 2003).

The ADA(2012) has set forth recommendations for school authorities on diabetes care in the school and day care setting, some of which are (1)opportunities for the appropriate level of on-going training and diabetes education for the school nurse (2) Level 1 training for all school staff members, which includes a basic overview of diabetes, recognition of hypoglycaemia and hyperglycemia, blood glucose monitoring, insulin administration and glucagon administration when a school nurse is not available (3) immediate accessibility to the treatment of hypoglycaemia by a knowledgeable adult. (4) accessibility to scheduled 


\section{International Journal of Science and Research (IJSR) \\ ISSN (Online): 2319-7064}

Index Copernicus Value (2015): 78.96 | Impact Factor (2015): 6.391

insulin at times scheduled by the healthcare provider (5) a location in the school that provides privacy during blood glucose monitoring and insulin administration (6) permission for the student to check his or her blood glucose level and take appropriate action to treat hypoglycemia in the classroom or anywhere the student is in conjunction with a school activity (7) permission for self-sufficient and capable students to carry equipment, supplies, medication, and snack; to perform diabetes management tasks; and to have cell phone access to reach parent and healthcare provider (8) permission for the student to see the school nurse and other trained school personnel upon request (9) permission for the student to eat a snack anywhere, including the classroom or the school bus, if necessary to prevent or treat hypoglycaemia (10) permission to miss school without consequences for illness and required medical opportunities to monitor the students diabetes management (11) permission for the student to use the restroom and have access to water as necessary (12) an appropriate location for insulin and or glucagon storage, if necessary (13) information on serving size and caloric, carbohydrate, and fat content of foods served in school.

In our study, it was encouraging that majority of the teachers $(97 \%)$ knew that DM was as a result of increased blood sugar levels, but not the various types of DM and majority $(81.8 \%)$ knew that DM causes complications in other organs. Knowledge of the visible complications of DM such as poor wound healing, foot ulcers and amputation appeared to be better than knowledge of non-visible complications such as loss of feelings in hands, fingers and feet.

Majority of the school teachers $(>50 \%)$ were able to recognize frequent urination, tiredness and weight loss as symptoms of DM. The study showed that knowledge regarding the risk factors for type 2 diabetes were poor with only $20.0 \%$ and $15.8 \%$ of the teachers reporting obesity and decreased physical activity as risk factors of DM. Not able to recognize obesity as a risk factor for diabetes may be due to the fact that overweight is considered as a sign of wealth in poor and developing countries. However, 35.3\%were able to state family history as a risk factor for DM.

Our study also showed that majority of the teachers (57.7\%) were not able to identify shaking and sweating as a sign of low blood sugar and $69.0 \%$ did not know the treatment for low blood sugar is to drink some sugar containing drink or eat food. But majority (75\%) knew that exercise lowers blood sugar.

Teachers' DM management practices were usually a reflection of their knowledge, beliefs and perceptions. Despite such perceptions, the most very important DM management practices cited by them were to allow student to see the school nurse upon request; discussing with parent about student condition, whiles they do not consider the rest of the management practices in table 3 as very important.

A reason for the lack of basic knowledge among school teachers includes lack of pre-service and in-service training on DM, since majority $(81.0 \%)$ of them reported that DM education should be added to the school curriculum and
$57.8 \%$ stated that the school should provide diabetic training for teachers.

In our study, the main sources of information about diabetes cited by the teachers were television and radio. This may be attributed to the recent awareness on diabetes by the media in Ghana. Doctors and nurses play insignificant role in educating teachers about DM from our study.

Our study is subjected to the following limitations. The low sample size limits the generalization of our findings. Nevertheless, our findings provide highlight what teachers know, and are willing to do for children with diabetes in schools. Also as in any self-administered questionnaire, the respondents' could suffer from recall bias.

\section{Conclusion}

The results reveal that teachers have inadequate knowledge of the basic facts of diabetes and management of children with diabetes in schools, a situation which could have dangerous consequences for the child with diabetes. Continuous in-service training programs in diabetes should be implemented in schools for teachers, which will prepare them to offer assistance to their students whenever it is needed.

\section{Author's Contribution}

IA contributed to the study concept and design. IA, $\mathrm{NAB}$, and SE contributed to interpretation and discussion of data. JPC contributed to the data collection and analysis of data.

\section{References}

[1] IDF Diabetes Atlas. Seventh Edition Update, IDF, 2015.Available from:http://www.eatlas.idf.org/Incidence/

[2] American Diabetes Association [ADA]. Care of children with diabetes in the school and day care setting. Diabetes Care. 2002; 26: S131-5.

[3] Ensaf,S and Gawwad A (2008), Teachers knowledge, Attitudes and Management Practices about Diabetes Care in Riyadhs Schools. J Egypt Public Health Assoc. Vol. 83. No. $3 \& 4$

[4] Kratzer J(2012): Structural barriers to coping with type 1 diabetes mellitus in Ghana: Experiences of diabetic youth and their families . Ghana Medical Journal, Vol 46, number 2 Supplement.

[5] American Diabetes Association (2008): Diabetes Care Tasks at School: What Key Personnel Need to know. Alexandria,VA, American Diabetes Association. (available online at $w w w$.diabetes/schooltraining).

[6] Wild S, Roglic G, Green A et al (2004) Global prevalence of diabetes: estimates for the year 2000 and projections for 2030. Diabetes Care .27: 1047-53

[7] Aycan, Zehra; Önder, Aşan; Çetinkaya, Semra; Bilgili, Hatice; Yıldırım, Nurdan; Nijat Baş, Veysel; Peltek Kendirci, Havva Nur; Yılmaz Ağladioğlu, Sebahat (2012).Assessment of the Knowledge of Diabetes Mellitus Among School Teachers within the Scope of 


\section{International Journal of Science and Research (IJSR) \\ ISSN (Online): 2319-7064}

Index Copernicus Value (2015): 78.96 | Impact Factor (2015): 6.391

the Managing Diabetes at School Program. Journal of Clinical Research in Pediatric Endocrinology. Vol. 4 Issue 4, p199

[8] Melton D and Henderson J.(2007) Do public schools provide optimal support for children with diabetes? Prev Chronic Dis. 4(3): A78.

[9] Wagner J, Heapy A, James A, Abbott G.(2006) Glycemic control, quality of life, and school experiences among students with diabetes. Journal of Pediatric Psychology Advance (Online). [cited 2007 March 8].Available from: Journal of Pediatric Psychology. 31(8):764-769; doi:10.1093/ jpepsy/jsj082.

[10]ADA.(2012) Diabetes care in the school and day care setting. Diabetes Care. 29 (1): 49-55.

[11] Hayes-Bohn R, Neumark-Sztainer D, Mellin A, Patterson J.(2004) Adolescent and parent assessments of diabetes mellitus management at school. J Sch Health. 74(5):166-9.

[12] Nabors L, Lehmkuhl H, Christos N, Andreone T (2003) Children with diabetes: perceptions of supports for selfcare at school. Journal of School Health. 73: 216-21.

[13] Husband A, Pacaud D, Grebenc K, McKiel E.(2001) The effectiveness of the CD-ROM in educating teachers who have a student with diabetes. Canadian Journal of Diabetes Care. 25(4): 286 - 90.

[14] National Institutes of Health: Helping the Student with Diabetes Succeed: A Guide for School Personnel. Bethesda, MD, National Diabetes Education Program. 